\title{
Chapter 7 \\ Czech and Slovak Research in Didactics of Mathematics
}

\section{Tradition and a Glance at Present State}

\author{
Jarmila Novotná, Marie Tichá and Naďa Vondrová
}

\begin{abstract}
This chapter presents the emergence of research in didactics of mathematics in the former Czechoslovakia and gives a glimpse at its present state. It is done against the background of the history of schooling in the area and with respect to international influences such as the New Math movement. Due to a limited access to international research prior to the Velvet Revolution in 1989, Czechoslovak research developed relatively independently, yet its character was similar to that of the West. An overview of research after the Revolution is divided into four streams: development of theories, knowledge and education of teachers, classroom research, and pupils' reasoning in mathematics. Each stream is described by relevant work by Czech and Slovak researchers (with a focus on empirical research) and illustrated by publications.
\end{abstract}

Keywords Mathematics education research - New math $\cdot$ History of schooling Czechoslovakia $\cdot$ Czech republic $\cdot$ Slovak republic

J. Novotná $(\bowtie) \cdot N$. Vondrová

Charles University, Prague, Czech Republic

e-mail: jarmila.novotna@pedf.cuni.cz

N. Vondrová

e-mail: nada.vondrova@pedf.cuni.cz

M. Tichá

Institute of Mathematics, Czech Academy of Sciences, Prague, Czech Republic

e-mail: ticha@math.cas.cz 


\subsection{Introduction}

\subsubsection{Aim of the Chapter ${ }^{1}$}

The aim of the chapter is to present roots and milestones in the origin and development of didactics of mathematics (mathematics education) as a science in the countries of the former Czechoslovakia. We base our ideas on a brief history of schooling and teacher education in the region. Next, we present how situations and events accompanying the emerging field of didactics of mathematics in other countries influenced the situation in our region.

The description of gradually developing research in mathematics education is naturally divided into two periods. The first period starts around the 1960s and ends with the Velvet Revolution ${ }^{2}$ in 1989 . The communist government at that time influenced all aspects of life, including research. Access of Czech and Slovak researchers to international research was very limited, so the field evolved in its own way. Unlike in many other fields, the work in mathematics education was little influenced by ideology. The second period spans the time after 1989 when mathematics education could develop freely and connect to international research.

The overview of research in the past 25 years or so strives to highlight the main research streams in both countries. We scrutinised publications of Czech and Slovak researchers to find their focuses and results. Some of them will only be mentioned, while others that we consider to be substantial are described in more detail. Finally, we briefly describe the main perspectives and challenges of mathematics education research as we experience them in the Czech Republic (CZ) and partially in Slovakia $(\mathrm{SK}){ }^{3}$

\footnotetext{
${ }^{1}$ The basis of the text is a chapter in a Czech book about the field didactics written by the same authors in 2015 (Vondrová, Novotná \& Tichá 2015). However, it has been substantially modified and augmented to include Slovak research and new research streams and to and to provide information to an international an international rather than a national audience.

${ }^{2}$ The Velvet Revolution was a non-violent transition of power in what was then Czechoslovakia. Demonstrations against the one-party government of the Communist Party of Czechoslovakia combined students and dissidents. The Revolution ended 41 years of one-party rule and began the dismantling of the planned economy and conversion to a parliamentary republic (https://en.wikipedia. org/wiki/Velvet_Revolution).

${ }^{3}$ For the sake of brevity, we will use acronyms $\mathrm{CZ}$ and SK when we refer to the respective parts of the former Czechoslovakia (which formally ended in 1992) or to the two newly established countries, Czech Republic and Slovak Republic after 1992.
} 


\subsubsection{Brief History of Schooling and Teacher Education in the Region}

Before looking at research in didactics of mathematics, we briefly present milestones of schooling and teacher education in the countries of the former Czechoslovakia as they highlight roots from which research not only in mathematics education has grown.

First, we must mention the personality of Jan Amos Comenius (1592-1670), who became the main representative of a socially committed pedagogy, particularly in Northern Europe. In his major work Didactica magna (The Great Didactic, 1657), he developed pedagogical principles that deeply influenced education in many European countries. According to Comenius, education should be: (a) universal, regardless of sex or financial means, and it is the state's task to ensure this; (b) realistic and ideas should at every step be grounded in reality; c) physical as well as mental and moral; and (d) practical, accompanied by action and practice. Moreover, (e) more science should be taught with the advancing age of the students, and (f) all education and knowledge should be directed to improving character and piety in the individual and order and happiness in the state (Jackson, 2011). Comenius attributed the main role to teachers. It was their task to 'provide interest and an atmosphere in the classroom in which the child will wish to learn' and 'to permit the child to observe for himself and arrange for the child to have direct experience in learning by doing' (Jackson, 2011, p. 99). Comenius's other influential texts such as Orbis Pictus (or Orbis Sensualium Pictus; The Visible World in Pictures, 1658) and Schola Ludus (Playful School, 1654) develop his pedagogical principles further. His ability to elaborate a genuinely pedagogical interpretation of didactics led to the establishment of pedagogy 'as a truly independent science based on criteria and principles epistemologically and gnosiologically' (Maviglia, 2016, p. 59).

Comenius's ideas continue to inspire teachers and researchers world-wide even today and they can indeed be seen in reform efforts throughout the history of CZ and SK, even though their implementation was not entirely successful. As early as 1774, six-year school attendance had already become compulsory in our region, which was accompanied by the onset of organised teacher preparation in the form of several-month courses. In 1868, an act was passed according to which primary school teachers were educated in four-year teacher education institutes (Mikulčák, 2010). It was a form of secondary education, accepting students after three years of secondary schooling, that contributed to considerable enhancing of teacher education standards. Graduation from these institutes and passing of 'maturita' (school leaving examination) did not constitute the full qualification. Prospective teachers had to complete practical education and pass an examination in pedagogical competence to acquire a professional qualification. Already at that time, teachers tried to elevate their education to a university level. Their efforts were supported by G. A. Lindner, 
a professor of pedagogy at the Faculty of Arts at Charles University, ${ }^{4}$ and others (Vališová \& Kasíková, 2011). However, after the establishment of Czechoslovakia in $1918,{ }^{5}$ the Ministry of Education as well as general public took a negative stance towards it. Consequently, primary teachers, supported by some university teachers of pedagogy, established a private School of High Pedagogical Studies using their own resources. Its two-year study program followed the study at a teacher education institute.

The preparation of secondary teachers was different. In the second half of the 19th century, teachers already had to take courses at faculties of arts or faculties of sciences. Their study mostly consisted of subject preparation and in some years also included a year of teaching finished by a practical examination (Mikulčák, 2010). Unlike primary teachers, secondary teachers complained about a lack of preparation in psychology and pedagogy.

The free development of schools and teacher preparation was disrupted by the Second World War, the period of German pressure on schools, and by the communist coup in 1948. After that, pedagogy was subordinated to ideologisation and to the Marxist-Leninist conception of scientific communism (part of which was also the communist conception of undifferentiated education). For more than 40 years (with some breaks such as the Prague Spring in 1968), there was a strong influence of the Soviet conception.

In 1946, provisions were set down for the establishment of faculties of education, mostly under universities, which educated primary teachers, so teachers of all levels of schooling were educated at the university level. However, already in 1953, the faculties were closed and, in 1959, institutes of education were set up bearing the title of regional universities. Faculties of education were brought into existence again in 1964 and have continued until today. Until 1989, teacher education in Czechoslovakia was unified at all faculties educating teachers. Not only the curricula, the textbooks and learning texts, but also the number of lessons, time allotment and students' duties were identical. The number of contact hours and study controls was rigorously defined and for future primary teachers divided into three approximately equal parts: one third was allocated for common background studies including pedagogy, psychology and teaching practicum, and the other two thirds were equally divided between two disciplines for which students were to be qualified. Future elementary teachers have since been educated as generalist teachers with an option to specialize in areas such as art, physical education and music.

\footnotetext{
${ }^{4}$ Charles University, one of the oldest European Universities, was founded in 1348. It was modelled on the universities in Bologna and Paris. The first university in the Slovak territory, Academia Istropolitana, was established in Bratislava in 1467; unfortunately, it lasted only about 20 years.

${ }^{5}$ After 1918, the educational systems of both main parts of Czechoslovakia also became very close because there was a lack of qualified Slovak teachers. That is why many Czech teachers came to Slovakia to teach between 1918 and 1939.
} 


\subsection{Emergence of Didactics of Mathematics as a Science}

In this section, some important milestones in the development of mathematics education (or the didactics of mathematics as it is called in $\mathrm{CZ}$ and SK) are described, both at an international and a national level. For the international level, only those aspects that substantially influenced the Czechoslovak (and later Czech and Slovak) research will be mentioned. By 'national perspective' we mean the Czechoslovak perspective.

\subsubsection{International Perspective}

The main characteristic of research in mathematics education in Czechoslovakia before 1989 was a very limited access to international research. Few researchers could travel abroad to Western countries to conferences, stay at foreign universities and have access to international proceedings and journals. Yet, some links were established. For example, there were mutual visits at universities: Researchers, mostly from the Faculty of Mathematics and Physics, Charles University, went to Germany (J. Šedivý, O. Odvárko, L. Boček, J. Mikulčák and others) and vice versa (H. G. Steiner, R. Stowasser, E. Wittmann and others). A few Czech or Slovak people were members of the scientific board or the editorial board of Zentralblatt für Didaktik der Mathematik.

The establishment of international organisations and conferences was indeed important for the development of mathematics education internationally and to some extent influenced the onset of research in Czechoslovakia. For example, a small number of researchers attended events such as ICMEs (the International Congresses on Mathematical Education), and reports were published in the Czechoslovak journals (e.g., Ripková \& Šedivý, 1986), or meetings of the International Mathematical Olympiad (e.g., J. Vyšín and academician J. Novák). An important event for the Czechoslovak research in mathematics education was the organisation of the International Symposium on Research and Development in Mathematics Education in Bratislava in 1988 and the publication of the proceedings ${ }^{6}$ (see Steiner \& Hejný, 1988). This was a rare event allowed by the communist authorities at that time.

By far the strongest influence on mathematics education, not only in Czechoslovakia, came from the New Math movement. Its spread in the country was heavily supported by Czechoslovak mathematicians and mathematics educators. This is documented, for example, by articles published in Czech journals by M. Jelínek, J. Šedivý and J. Vyšín, which influenced the movement in Czechoslovakia (see Sect. 7.2.2).

Regardless of the limited access to international results in Czechoslovakia, some researchers and their work profoundly influenced mathematics education research in Czechoslovakia (and continue to do so). ${ }^{7}$ First, we must mention

\footnotetext{
${ }^{6}$ The conference had two follow-up meetings.

${ }^{7}$ Many of the seminal books on mathematics education were available to $\mathrm{CZ}$ and SK researchers in Russian translations only (e.g., G. Polya: Kak resat zadacu).
} 
the work by H. Freudenthal (the concept of guided reinvention, 1972, 1986, 1991). Much input came from Polish and Hungarian mathematicians and mathematics educators such as Z. Krygowská (1977), Z. Semadeni (1985), S. Turnau (1980), G. Polya (1945) and T. Varga (1976). Among others, we will mention E. Castelnuovo from Italy (New Math movement), G. Brousseau from France $(1997)^{8}$ and E. Wittmann from Germany (Project Mathe 2000; mathematics education as a design science and the idea of substantial learning environments, 1981). Obviously, we only mention researchers whose influence in the former Czechoslovakia can clearly be seen in publications and presentations of $\mathrm{CZ}$ and SK researchers. There were certainly others whose work influenced research in mathematics education for individuals and who cannot all be listed here.

In the next section, we will elaborate on the roots of mathematics education research from the national perspective, which comprises both countries in question.

\subsubsection{National Perspective}

In the first half of the 20th century, we cannot yet speak about scientific work in mathematics education. In Czechoslovakia, there was no specific institution or workplace whose task would have been to work in mathematics education, especially since it was not part of teacher education. The only books dealing with mathematics education issues were textbooks for pedagogical institutes such as K. Hruša's Methodology of Counting (1962). Many distinguished mathematicians were interested in education, which can be seen in their authorship of mathematics textbooks. For example, B. Bydžovský and J. Vojtěch published textbooks in the first half of the 20th century and E. Čech during the Second World War. From today's perspective, it is interesting that E. Čech valued the mathematical knowledge of mathematics teachers and also emphasised that how we teach is important, not only what we teach (Vyšín, 1980).

The interest of $\mathrm{CZ}$ and SK mathematicians in education and the responsibility they felt for it showed itself during the New Math movement, which appeared in the Czechoslovak context as modernisation of teaching mathematics. The Union of Czechoslovak Mathematicians and Physicists (or in some times of its history, Czech) ${ }^{9}$ took the initiative and organised seminars and conferences (some of which

\footnotetext{
${ }^{8}$ Some parts of G. Brousseau's work (e.g., 1997) were translated into Slovak by I. Trenčanský et al. in 2011 and into Czech by J. Novotná and colleagues in 2012.

${ }^{9}$ This was founded in 1862 as the Verein fur freie Vorträge aus der Mathematik und Physik (Club for Free Lectures in Mathematics and Physics), and in 1869 it was renamed Jednota českých mathematiků (Union of Czech Mathematicians). It has always united both mathematicians and mathematics teachers. It was also a founding member of the European Mathematical Society. Among other activities, the Union publishes scientific journals. It started to publish Časopis pro pěstování matematiky a fyziky (Journal for Fostering Mathematics and Physics) in 1872 (it exists to this day under the name Mathematica Bohemica). In 1922, it established a journal for secondary pupils called Rozhledy matematicko-fyzikální (Mathematics-Physics Horizons) and in 1948 a journal for
} 
still exist today), both in CZ and SK, where these issues were discussed. Renowned mathematicians such as E. Čech, V. Kořínek, J. Kurzweil, T. Šalát, M. Kolibiar and M. Švec supported the movement. More importantly, the Union established the Department for Modernisation of Teaching Mathematics and Physics, whose mathematical part became part of the Mathematical Institute of the Czechoslovak Academy of Sciences in 1969. The goal of the Department was to support cooperation among researchers. Its research paradigm gradually developed, which was reflected in the change of its name to the Department for the Didactics of Mathematics in the early 1980 s.

In the 1960s and 1970s, many articles and books were published about modernisation that concerned not only the methods of teaching but also mathematics education. Moreover, research work in mathematics education was included in the State Plan of Fundamental Research, and, in 1965, scientific education in the theory of teaching mathematics ${ }^{10}$ was established, which can be understood as the official beginning of scientific research in mathematics education in Czechoslovakia. Dissertation theses in this new field were to include the following sections, which, in fact, correspond to current requirements: the current state of the problem, goals, methods, results and conclusions, including recommendations for future research. Some examples of research in mathematics education before 1989 are given in Sect. 7.2.3.

After the Velvet Revolution in 1989, researchers in mathematics education from Czechoslovakia became more active internationally. The foundation of the European Society for Research in Mathematics Education (ERME) in 1997 already had Czech and Slovak participation. Some researchers became members of editorial boards of journals (such as Educational Studies in Mathematics, Journal of Mathematics Teacher Education and The Mediterranean Journal for Research in Mathematics Education) and started to work on common projects with researchers from abroad; important international conferences were organised in CZ (SEMT, 1991-2017; ERCME, 1997; PME, 2006; ESU5, 2007; CIEAEM, 2006; CERME, 2001 and 2015, and YERME Summer School, 2004 and 2016). Researchers became members of international teams working on a common topic such as the Learner's Perspective Study (see Sect. 7.3.4) or the Lexicon Project (Clarke et al., 2016).

To sum up, in this section, we saw one of the four features identified as relevant for European didactic traditions, namely the importance of the strong connection of mathematics education research with mathematics and mathematicians (see Sect. 1.2). Czech and Slovak mathematicians indeed felt responsibility for the teaching of mathematics, were authors of textbooks, participated in the education of mathematics teachers and actively helped to introduce New Math principles in the former Czechoslovakia. Moreover, one of the roots of mathematics education research is based in the Institute of Mathematics of the Czech (Czechoslovak) Academy of Sciences, with which the first researchers in mathematics education were affiliated.

mathematics teachers, Matematika a fysika ve škole (Mathematics and Physics in School), which still exists under a slightly different name. Articles from these journals are currently freely available online in a digital mathematical library (www.dml.cz).

${ }^{10}$ Until then, researchers had to get academic degrees in mathematics or pedagogy. 


\title{
7.2.3 Czechoslovak Research in Mathematics Education Before 1989
}

An important feature of emerging research in mathematics education was, probably thanks to its growth from practical issues (to verify new ways of teaching within the modernisation movement), the idea that research on teaching and curricular research had to be carried out in parallel. Changes in teaching practice needed to be combined with proper and long-term research (e.g., Kraemer, 1986). It was felt that research must be done both on the theoretical and practical levels:

\begin{abstract}
'fundamental research in teaching mathematics' and 'the didactics of mathematics' can be seen as two fields living in a tight symbiosis.... Fundamental research is, in fact, experimental didactics and the theory of teaching mathematics is enriched by its results. On the contrary, when doing fundamental research, all present results from the theory and practices of teaching mathematics are used. (Vyšín, 1976, p. 582; authors' emphasis)
\end{abstract}

Thus, research focused on the construction, implementation and evaluation of curricula. Experimental textbooks were written and implemented at least three times and their use was rigorously evaluated, in the spirit of the present idea of design experiments.

For example, at the time of modernisation, new teaching texts were written for Grades 1-3 and used in teaching at experimental schools established throughout Czechoslovakia. Teachers were not only educated to master the new material but also to acquire new teaching methods. Pupils were given tests to see what they learned from the new texts and results were mostly elaborated in a quantitative way (with some exceptions involving qualitative research through interviews with pupils). A 100-page research report was written by researchers from the Department of the Didactics of Mathematics of the Mathematical Institute of the Czechoslovak Academy of Sciences (such as J. Kittler, M. Koman, F. Kurrina and M. Tichá), depicting the theoretical background and course of the teaching experiments with their results. A substantial part of the report consisted of conclusions highlighting necessary changes in the teaching material and its implementation and recommendations for further research. This report was reviewed by four reviewers and openly defended before stakeholders (including teachers) in 1973. Similarly, a report which concerned Grades 6-9 was defended in 1977 and a report for Grades 1-5 in 1987. Alongside this more substantial research, small-scale experiments were carried out that aimed at specific topics such as geometry, number sense and assessment (e.g., Vyšín, 1972).

It must be stressed, however, that there were two branches of research before 1989. The first was applied research realised by the Research Institute of Pedagogy and by the Research Institute of Vocational Education: Its focus was on the change of the curriculum. Fundamental research was realised by the Czechoslovak Academy of Sciences (including the Mathematical Institute with its Department of the Didactics of Mathematics ${ }^{11}$ ) and by some universities, and attempts were made to connect it

\footnotetext{
${ }^{11}$ It had a small number of its own researchers but cooperated with a number of researchers from universities and with mathematics teachers.
} 
to applied research. The above-mentioned duality probably caused these efforts not to be entirely successful. There was no adequate reaction to the results of New Math research abroad and of local fundamental research that pointed out weak points of the New Math movement. Teaching based on set theory that influenced the West in the 1960s was introduced to schools in Czechoslovakia in 1976. However, at the same time, in schools connected to the Department of the Didactics of Mathematics, new teaching texts were already being prepared based on results from experimental teaching between 1965 and 1972 (as given in the reports mentioned above), and teaching with a set as a central concept was gradually abandoned there.

In the next period of fundamental research, when a new model of mathematical education was being sought, more attention was paid to psychological and pedagogical aspects. Its idea was that the experience pupils had before coming to school should be used more and the style of work at school should be more active. Pupils should be encouraged to work with both non-mathematical and mathematical models to acquire deep understanding of mathematical concepts. In school mathematics, there was a shift from syntactic (structural) to semantic (genetic) conceptions. For example, the ideas of assigning, dependence and variability became central when teaching functions. Explicit connections were made between school mathematics, the real world and other school subjects (Koman \& Tichá, 1986, 1988).

A two-way connection between mathematics and real-world issues was in the heart of 'task environments' elaborated by J. Vyšín and M. Koman. Their focus was not on the application of mathematics in pupils' worlds only but also on impulses coming from the pupils' worlds for the building of mathematics. Vyšín (1973) emphasised that we should not teach the application of mathematics but rather mathematics that can be applied. Interestingly, Freudenthal (1991) says something similar: 'Applying mathematics is not learned through teaching applications. The so-called applied mathematics lacks mathematics' greatest virtue, its flexibility. Ready-made applications are anti-didactical.' (p. 85)

At the beginning of the 1980 s, the main areas and characteristics of experimental teaching and the conception of fundamental research for the period 1981-1990 were formulated by the members of the Department of the Didactics of Mathematics. These consisted, among others, of lowering factual teaching, elaborating a psychologicalgenetic approach, more focus on mathematical methods (problem-solving methods), so-called mathematical laboratories ${ }^{12}$ and problem teaching, and conducting research on introducing calculators in teaching mathematics. On the state level, teams of 5-10 researchers from universities, the Mathematical Institute and schools were formed, and each team suggested a research problem the team wanted to solve. Some examples were a team led by M. Koman that studied functions (e.g., Koman \& Tichá, 1986), a team led by F. Kuřina that focused on geometry (e.g., Kuřina, 1976;

\footnotetext{
${ }^{12}$ Mathematical laboratories consisted of methods that helped pupils become active and in which a teacher encouraged their discovery, experimenting etc. Nowadays, we would speak about inquiry teaching as a constructivist approach to teaching. Mathematical laboratories remained mostly in theory and existed in experimental schools affiliated with the Mathematical Institute.
} 
Koman et al., 1986) and a team led by M. Hejný that developed the methodology of research (Hejný et al., 1988).

Before 1989, important sources of new ideas in mathematics education were dissertation theses in the above-mentioned theory of the teaching of mathematics. An example is M. Tichá's unpublished dissertation from 1982 called To Strategies of Problem Solving in Teaching Pupils Mathematics at the Lower Secondary School. It concerned the evaluation of the use of a pilot text of J. Vyšín (Propositional Forms): Its goal was to find out whether, by a suitable organisation of learning conditions, pupils were not only able to master problem-solving methods but were also able to work creatively with these methods. The author used a mixed methodology of research that combined a written test with interviews of 65 randomly selected pupils. The work showed, among other things, that the graphic method helps pupils to solve word problems on movement and that even though the teacher usually emphasises a calculation method for these problems (a system of equations), pupils use insight (common sense) first, experiments next and finally equations. Research on pupils and their reasoning started to be a major focus.

A work unique in its size, character and impact was published by Slovak researchers, M. Hejný and colleagues in $1988 .{ }^{13}$ It is a comprehensive book addressed to teachers, teacher educators and researchers. It covers all parts of secondary school mathematics in a mathematics-didactic way. Not only are there suggestions for teaching the appropriate subject matter, these suggestions are also documented by teaching experiments and interviews with pupils and teachers and augmented by mathematical problems to solve (some of which are quite complex). The didactic elaboration of topics is framed by a concept-development theory called later the theory of generic models (see Sect. 7.3.2). The authors managed to connect the mathematical, methodical, pedagogical and psychological aspects of mathematics education in a way that has inspired new researchers since. The book is still used for the education of future mathematics teachers and Ph.D. students in mathematics education.

Until 1989, the tendency in CZ and SK research went through a series of changes of focus: a one-sided emphasis on mathematical content, the contribution of mathematical education to the education of pupils and teachers, the teachers' and pupils' role in the teaching-learning process, pupils' mathematical culture, the professionalization of teachers' work, and similar aspects. After the Revolution, the character of research work has changed in the same way as opportunities have arisen such as access to international literature and research communities or grant projects. However, the experience from fundamental research realised before 1989 positively influenced mathematics educators' competence to carry out research. Unlike in most fields of didactics in $\mathrm{CZ}$ and $\mathrm{SK}$, in which research had to be established from scratch after 1989, research in mathematics education has never really been disrupted, regardless of the difficulties researchers met under the communist regime.

\footnotetext{
${ }^{13}$ As the leading author had problems under the communist regime and could not publish freely, the book was published as a second volume to show that it was a sequel to the existing book Teoria vyučovania matematiky 1 and thus must be published. But, in fact, it is a stand-alone book, not connected to its namesake.
} 
To sum up, in this section we saw two more of the four features identified as relevant for European didactic traditions (see Sects. 1.4 and 1.5). First, a key role of design activities for learning and of teaching environments can already be seen in the design and testing of materials for the New Math movement, and it remains so until today. In our tradition, we can also distinguish an empirical turn similar to the German one (see Sect. 5.2.3), from 'Stoffdidaktik' focusing strongly on mathematical content for direct use in lessons to design activities done to study the effect of didactic variables in classroom experiments. Again, the New Math movement greatly contributed to this change. Second, another feature of the Czechoslovak tradition is the basis in empirical research using various research methods. The research is usually on a small scale, and before 1989 it was strongly connected to the experimental primary schools mentioned above.

\subsection{Mathematics Education Research in the Czech Republic and in Slovakia After 1989}

Since the political change in 1989, the field of mathematics education has developed against a background of big changes in education and teacher education brought about by reform efforts. These were mostly promoted by educationalists, so naturally, many of Comenius's ideas can be found in their background in CZ. For example, the key policy document, the National Programme for the Development of Education in the Czech Republic, the so-called White Paper (2001), strives to revive Comenius's plea for universal education and brings forward principles that would ensure an access to education to every single individual regardless of age, class, gender and nationality. Even more profound was the (unvoiced) influence of Comenius's ideas on the main curricular documents, the Framework Educational Programmes, mainly in the conception of key competences that the school should develop. For example, learning competencies and problem-solving competencies are based on Comenius's principle of systematicity, autonomy and activity (Smílková \& Balvín, 2016). The other competencies (communication, social and personal, civil and working competencies) are directly linked to Comenius's principles. The same is true for cross-curricular subjects that are introduced in the documents and that make an inseparable part of basic education and represent its important formative element, namely, personal and social education, democratic citizenship, education towards thinking in European and global contexts, multicultural education and environmental education.

Comenius and his work are alive in CZ, not only in works of researchers from the Department of Comenius Studies in the Czech Academy of Sciences. His ideas are not only embedded in textbooks for university studies of future teachers but also in disciplines such as social pedagogy, philosophy and religion. Comenius's influence in mathematics education can be traced as well even though it is not always stated; his ideas are embodied in the milieu within which researchers work. Researchers 
often refer to Comenius's work when promoting visualisation in teaching, learning by doing and by using several senses, learning by playing, and the like, or life-long learning.

\subsubsection{Methodology}

In the last 25 years or so, research in former Czechoslovakia has been rather diversified. The common history of the Czech Republic and Slovakia was disconnected in 1993 when Czechoslovakia was separated into two countries: the Czech Republic and the Slovak Republic, who have had independent developments. Due to the same roots, educational systems and teacher education in both countries are still close, and naturally there is cooperation among researchers from both countries. Thus, we can present research in both countries together.

Roughly, the research can be divided into three branches. The first one is orientated towards the study of thinking processes of pupils and teachers, communication in teaching and learning mathematics, climate of the classroom, and the whole sociocultural context. The second branch is on investigating curriculum, mathematical content, textbooks and so on. Obviously, these two branches are closely connected, even though sometimes the connection is not considered in CZ and SK research. The third branch focuses on the history of mathematical ideas and strives to find inspirations for mathematical education in it. This chapter mostly concentrates on the first branch because its basis is mainly empirical research, and quality publications in English are available. It will be divided into four streams, in which main research studies will be briefly summarised and illustrated by representative examples of publications. We have given priority to English or German publications originating from a particular research study (if they exist at all) over Czech or Slovak ones even when the latter are newer or more comprehensive so that an international audience can have access to them. Naturally, some research sits at the border of our identified streams; for example, sometimes pupils' reasoning is studied in relation to teachers' knowledge. Nevertheless, we decided to make these distinctions for the sake of clarity.

When trying to distinguish main research topics and to find relevant publications by $\mathrm{CZ}$ and SK authors, we scrutinised scientific journals, proceedings of international conferences and books to which we had access. We searched the database of prestigious research projects awarded by the Grant Agency of the Czech Republic (GA ČR) and its Slovak counterpart, the Scientific Grant Agency of the Ministry of Education of the Slovak Republic (VEGA). For the Czech part, we also used results of a survey conducted in 2013 at all universities educating future mathematics teachers done by the former Accreditation Committee established by the Ministry of Education, Youth and Sport. In this survey, the universities were asked to include the most important publications on research in mathematics education written by their employees. For the Slovak research, we contacted our research colleagues from Slovakia to direct us to results of Slovak research that we were not familiar with. 
We do not present work done by Czech or Slovak researchers who have gone to work abroad (such as J. Višňovská or J. Trgalová).

We realise that our description of the state of affairs must necessarily be incomplete. Research publications may result outside of awarded grant projects or outside of universities educating mathematics teachers. Moreover, we base our considerations on published results only and mostly on empirical research. There may be on-going research without any publication known to us. Finally, we would like to stress that the research described below should be understood as a continuation of research up to the Velvet Revolution as described in previous sections.

\subsubsection{Development of Theories}

Another of the identified main features of European traditions (see Sect. 1.3) is the key role of theory. Unlike the French tradition, in which research in mathematics education has evolved around three basic theories (see Sect. 2.1.2), the situation in $\mathrm{CZ}$ and SK is more diversified. However, we can say that most research is based on the constructivist theory of learning, which has been elaborated in the local context as didactic constructivism (Hejný \& Kuřina, 2009). M. Hejný and F. Kuřrina formulated 10 principles of didactic constructivism that have influenced teaching, teacher education and research in mathematics education in $\mathrm{CZ}$ and to a lesser extent in SK. One of the principles is an emphasis on pupils' mathematical activity consisting of looking for things such as relationships, problem solving, generalising and argumentation. Another is the creation of the kind of environment in a lesson that supports creativity and is the basis of learning mathematics. The principles also stress the importance of pupils' mistakes and the way teachers can handle them to develop pupils' knowledge. This aspect has affected both research and teaching in $\mathrm{CZ}$ and SK.

In terms of concept-development theories, by far the most influential one in $\mathrm{CZ}$ and SK is the theory of generic models that was originally developed by M. Hejný in Bratislava in the 1980s and later in Prague. Unfortunately, the theory is not described in its entirety in English. The most comprehensive book about it is in Czech (Hejný, 2014). Elements of the theory are described in various publications such as Hejný (2012), Hejný and Kuřina (2009) and Stehlíková (2004). In brief, the theory describes concept development in mathematics as consisting of several levels, beginning with motivation, through the stage of isolated models (concrete cases of future knowledge) and the stage of generic models (which comprise all isolated models and can substitute for them) up to the abstract knowledge level. ${ }^{14}$ There are two shifts between the stages: generalisation and abstraction. The latter is accompanied by a change in

\footnotetext{
${ }^{14}$ For example, when pupils solve a problem on generalising a pattern represented by several numbers, they first calculate several other elements of the sequence and thus work with isolated models. Later, they can see a rule and are able to use it for the calculation of further elements: They have found a processual generic model. Next, they are able to state in words how any element of the sequence can be found without having to calculate the preceding elements: They have found a
} 
language (for example, the language of algebra is used). Crystallisation is the term used for the process of connecting new concepts to old ones and using it to build new knowledge in the future. Within this theory, insufficient understanding is captured by the term mechanical understanding, which means knowledge that is not supported by generic models and is mostly grasped by memory only.

This theory has been successfully used by researchers in CZ, SK and Poland for the description of the construction of knowledge from different fields of mathematics for pupils and students of different ages (e.g., Jirotková \& Littler, 2002; Jirotková \& Slezáková, 2013; Krpec, 2016; Robová, 2012; Stehlíková, 2004; Vaníček, 2009). ${ }^{15}$ On the one hand, the theory has practical applications, the most prominent being a new approach to teaching called scheme-based education (Hejný, 2012). On the other hand, L. Kvasz embraced the theoretical foundations of the theory and the teaching style based on it by formulating the principles of so-called genetic constructivism (Kvasz, 2016) to show that it differs from radical constructivism with which it is sometimes identified in the local context. L. Kvasz grounds his arguments in the genetic approach to mathematics, which is based on a thorough understanding of the history and epistemology of mathematics.

While the theory of generic models had to be described here, as it is mostly rooted in $\mathrm{CZ}$ and SK, the other theories which are often used by Czech and Slovak researchers do not require such a description. Very influential is the theory of didactical situations developed by Brousseau (1997). The theory is mostly used by J. Novotná and her collaborators in CZ and by I. Trenčanský, L. Rumanová and E. Smiešková in SK. For the research aimed at future teachers, Shulman's (1986) theory is mostly used as well as Ball and colleagues' practice-based theory of mathematical knowledge for teaching (Hill et al., 2008). Research focusing on a teacher's use of technology is carried out against the background of technological pedagogical content knowledge (TPACK; Mishra \& Koehler, 2006).

\subsubsection{Knowledge and Education of Future Elementary and Mathematics Teachers}

Knowledge and education of future elementary and mathematics teachers have attracted much attention in $\mathrm{CZ}$ and $\mathrm{SK}$; however, much of it has been in the form of theoretical studies or recommendations, which are not our focus here. In terms of empirical research, one strand of research aims at mathematical knowledge for teaching of future elementary teachers (Marcinek \& Partová, 2011; Partová et al., 2013; Samková \& Hošpesová, 2015), for example, knowledge about geometric shapes, which has been investigated within a VEGA project aimed at geometric conceptions

conceptual generic model. When they are able to write an algebraic expression for the $n$th term of the sequence, they are at the abstract level.

${ }^{15}$ The theory has also been used in many dissertation and diploma theses. 
and misconceptions of both pre-school and school age children and future teachers (Duatepe-Paksu et al., 2017; Žilková et al., 2015).

Another strand aims at pedagogical content knowledge of future teachers. First, problem-posing competence of future teachers, understood as an educational, motivational and diagnostic tool, has been studied in Tichá and Hošpesová (2013). Their analysis of the problems posed by the students revealed, among other things, shortcomings in their conceptual understanding of some notions, especially fractions. Classroom-based joint reflection became the means of re-education. Problem posing of pre- and in-service teachers and the way they reflect on the posed problems has been a focus of Hošpesová and Tichá (2015). They have confirmed, among other things, that problem posing on its own is by no means a sufficient tool for the remedy of teachers' misconceptions. It works best in combination with reactions from others. Some ways have been shown in which teacher educators can guide joint reflections to achieve best results.

The second focus is on a professional vision of future teachers, both in terms of their patterns of attention in general and attention to mathematics-specific phenomena in particular (Vondrová \& Žalská, 2015), and possibilities for the development of a professional vision in a control versus experimental group intervention study (Simpson, Vondrová \& Žalská, 2018). While the latter study confirmed many results of research on professional vision of future mathematics teachers in terms of their pattern of attention (for example, more attention to the teacher than to the pupils, more attention to pedagogical issues rather than to issues connected with the teaching of mathematical content), it showed a markedly different development in student teachers' knowledge-based reasoning (unlike in related literature, there was no shift towards interpretation of noticed events and issues).

The third focus is on future teachers' TPACK or its aspects (Beňačka \& Čeretková, 2015; Jančařík \& Novotná, 2013; Kapounová et al., 2013). Finally, we will mention skills and knowledge that future teachers should possess when teaching content and language-integrated learning (CLIL), which refers to any learning context in which content and language are integrated in order to fulfil specified educational aims (Marsh \& Langé, 1999). Moraová and Novotná's $(2005,2017)$ research is an example of examining ways of introducing this teaching strategy to future teachers.

Teachers' teaching practices, beliefs and ideas are also topics of research. For example, their views of what they consider critical parts of mathematics for their pupils' understanding and how they deal with them in their teaching were the centre of attention in a GA ČR project (Rendl et al., 2013). According to teachers, pupils tend to make more mistakes when more rules and procedures are learnt. When the knowledge is needed for a task at a later time, there can be interference among the variety of knowledge already learnt, and pupils have more tendency to fail if the task does not include an explicit reference to the necessary knowledge and instead the knowledge is only implied. The solution teachers have offered consists of further revision and drill; however, it is not clear whether an intended goal of the revision and drill is also to deepen conceptual understanding or whether there is an overreliance on its spontaneous emergence. 
Teachers' educational styles are investigated in Hejný (2012) and Jirotková (2012). The authors have developed (and applied) a diagnostic tool that can be used for the characterisation of a teacher's educational style. The tool consists of 20 parameters divided into four areas: beliefs, experience, personality and abilities/competences. The tool can be used for the development of the teacher's teaching style as well.

Collective reflection has been studied as a means of influencing teachers' beliefs. The springboard of research on reflection was the cooperation with elementary teachers that naturally led to action research and the study of its various conceptions, including its importance for collaborative continuing professional development (Benke et al., 2008). Reflection is understood not only as one of the competences but also as one of the ways of developing this competence. Tichá and Hošpesová (2006) based their research on samples of teachers' reflections and showed their gradual development from merely being simple conversations based on intuitive perceptions through searching for effective teaching approaches, to the deep assessment of mathematics teaching from the point of view of topics and their didactic elaboration, and to suggestions for the teachers' own experiments.

The cooperation between researchers and teachers is mainly focused on case studies (Jirotková, 2012; Tichá \& Hošpesová, 2006), which document the developments of teachers' knowledge and beliefs. The question of teachers as researchers is investigated, for example, in Novotná et al. (2003) and in a broader context in Novotná et al. (2013). The latter work focuses on teacher education and its development and introduces, among other things, several categories of mathematics educators. Observations are discussed as important means of learning in both teachers' and researchers' practices.

\subsubsection{Classroom Research}

An interest in classroom research naturally stems from the need to understand situations that appear in the classroom and that enable the development of pupils' mathematical knowledge.

First, we mention extensive classroom research within the Learner's Perspective Study project, whose goal has been to conduct international comparative studies of teaching mathematics. Its characteristic feature is that 10 successive lessons are video-recoded, described by artefacts and complemented by interviews with the teacher and with some pupils. Results are published in a series of books in which Czech researchers also have chapters (Binterová et al., 2006; Novotná \& Hošpesová, 2010, 2013, 2014). The chapters include analyses of teaching situations from both national and international perspectives. They bring insight into the outer and inner stereotypes in lower-secondary mathematics lessons from the viewpoint of, for example, classroom environment, algebraic competence and its development, coherence between educational goals and school practice when teaching word problems, active involvement of pupils in concept development and the like. 
Much research of processes in mathematical lessons has been conducted in $\mathrm{CZ}$ in connection with doing trials of a specific way of teaching mathematics at the primary school level mentioned above, the so-called scheme-based education ${ }^{16}$ which is developed in the research team around M. Hejný (Hejný, 2012, 2014; Jirotková \& Slezáková, 2013). This teaching is based on the above theory of generic models. Mathematical knowledge is built based on pupils' active work within carefully developed learning environments that permeate all grades of the primary school. They meet the requirements of substantial learning environments as introduced by Wittmann (1995). The teacher's role in teaching mathematics is that of a facilitator. The studies of scheme-based education are of an exploratory nature, bringing insight into how pupils reason in mathematics during a lesson conducted in the frame of scheme-based education (e.g., Jirotková \& Slezáková, 2013; Krpec, 2016).

Classroom research also plays an important role in three research projects awarded funding by GA ČR. The first investigated the development of mathematical literacy at a primary school (Hošpesová et al., 2011). Among other things, the project provided reasons why we should emphasize links between and blending of a teacher's mathematical competences and didactic issues in that it justifies an emphasis on systematic practice in which pupils construct their own mathematical world. The project demonstrated the importance of the role that arithmetical, algebraic and geometric models play in the development of notions of mathematical objects and relations between them and in solving problems stemming from real-life situations.

The second project focused on the use of textbooks (not only in mathematics) at lower-secondary schools (Sikorová, 2011). It showed, for example, that practising mathematics teachers used the textbook mostly as 'a source of the tasks' and for simple activities such as reading the text.

The third project aimed at the development of the culture of solving mathematical problems in school practice. Its focus was pupils' solving strategies, their reasoning, mistakes and the use of research results in school practice (Eisenmann et al., 2015). The research was longitudinal. Lower- and upper-secondary pupils were exposed to the use of selected heuristic strategies in mathematical problem solving for a period of 16 months. A tool was developed that allows for the description of their ability to solve problems and that consists of four components: intelligence, text comprehension, creativity and the ability to use existing knowledge. After the experimental teaching, the pupils appeared to considerably improve in the creativity component and there was a positive change in their attitude to problem solving. The teaching style of the teachers participating in the experiment showed a significant change towards a more constructivist, inquiry-based approach and in their willingness to accept a pupil's non-standard approach to solving a problem.

Finally, we will mention intervention studies of an experimental versus control group type, which are not frequent in published CZ and SK research ${ }^{17}$ (e.g., Sedláček,

\footnotetext{
${ }^{16}$ A scheme is understood in the sense of Gerrig (1991) as a memory structure that incorporates clusters of information relevant to comprehension. Hejný's conception of a scheme builds on Piaget's conception and is close to Dubinský and McDonald's (1999).

${ }^{17}$ Many studies only include an experimental group (e.g., Bero, 1993; Binterová \& Fuchs, 2014).
} 
2009; Slavíčková, 2007). In Cachová’s (2011) study, the experimental group of Grade 1 pupils working with calculators performed the same as the control group working without them in tasks and were more motivated than the control group. In Huclová and Lombart's study (2011), the experimental group of pupils working with software only when learning about line symmetry picked up some unsuitable construction steps based on the way the software made them perform these steps. Vankúš (2008) investigated game-based learning mathematics and found that it improved pupils' motivation and attitudes to mathematics but that there was no difference between the experimental and control groups in terms of mathematics knowledge acquired.

\subsubsection{Pupils' Reasoning in Mathematics}

Probably most attention in CZ and SK research has been devoted to pupils' strategies, reasoning, mistakes and misconceptions in concrete parts of mathematics. Some examples of these areas of study are fractions (Tichá, 2000), geometric reasoning and conceptions (Budínová, 2017; Kopáčová \& Žilková, 2015; Pavlovičová \& Barcíková, 2013), non-sighted pupils’ perception of space and its objects (Kohanová, 2007), word problems ( Eisenmann et al., 2015; Hejný, 2006; Tichá \& Koman, 1998), solids (Jirotková \& Littler, 2002), infinity (Cihlář et al., 2015; Jirotková, 1998), measurement in geometry (Tůmová \& Vondrová, 2017), representations of multiplication (Partová \& Marcinek, 2015) and combinatorial problems strategies (Janáčková, 2006).

A GA ČR project (see Vondrová et al., 2015) focused on interviews with pupils solving problems from critical areas of mathematics as identified by teachers (see Sect. 7.3.3). Research revealed, among other things, a strong tendency of pupils towards the use of formulas in geometry and preference to calculations over reasoning (which was not mentioned by the interviewed teachers). Deficiencies were identified in the mental representation of a continuum of rational numbers, the conceptual understanding of an algebraic expression as an object to be manipulated (as opposed to procedural problems reported by the teachers), the breach of relationships between theoretical and spatial-graphic spaces when interpreting and using a picture in geometry, and the conceptual understanding of measure in geometry. A serious problem was identified in word problems. There was no direct correspondence between some language expressions and their mathematical descriptions in numbers and variables. A relationship between language literacy and problem solving is currently being investigated within a new GA ČR project aimed at parameters influencing the difficulty of word problems where only preliminary results have been published (e.g., Vondrová, Novotná \& Havlíčková, 2018).

On the one hand, research attention has been focused on pre-school children and their reasoning. For example, problem solving and the diversity of pupils' solutions (Kaslová, 2017), geometric ideas (Kuřina, Tichá \& Hošpesová, 1998), and children discovering mathematical concepts and strategies in a learning environment (Jirotková \& Slezáková, 2013). On the other hand, the development of mathematical 
knowledge of university students has also been studied (Simpson \& Stehlíková, 2006; Stehlíková, 2004). For example, the former study documented that in the development of an examples-to-generality pedagogy, an emphasis on the guidance of joint attention is needed rather than the free-for-all of unguided discovery, that is, on teachers and learners making sense of structures together, with the teacher able to explicitly guide attention to those aspects of the structure that will be the basis of later abstraction and to the links between the formal and general with specific examples.

A specific place in this stream of research is held by work on the use of technology in mathematics education. Many studies on this topic written by $\mathrm{CZ}$ and SK authors have focused on a mathematical content and how it can be presented "better" or "more easily" via technology. Mathematical problems have been suggested that can be used in, for example, GeoGebra and sometimes given a trial with a small number of participants. Such studies may function as springboards for empirical research and are valuable in their own right for actual teaching. However, as they are not research reports as such, we will not address them further here.

Two Czech comprehensive books on technology have influenced the field in CZ. Vaníček (2009) presents ways dynamic geometry software can enhance the teaching of mathematics and points to some perils of the software, using personal results of teaching experiments and experience from teacher education. Against the background of pupils' active learning of mathematics, Robová (2012) analysed results of research on the use of ICT and presented a comprehensive account of the merits and perils of ICT use in the teaching of mathematics. For the first time in CZ research, she focuses on the use of internet material and forums in teaching. She argues that the successful use of ICT must be accompanied by a change in a teacher's teaching styles, which is often not the case. Moreover, in Robová (2013), she presents skills that pupils should develop to overcome the problems she identified in their use of ICT tools. Examples are estimation skills, understanding dependence and congruence of objects in a dynamic software, and zooming in and out.

\subsection{Current Situation, Perspectives and Challenges}

In this chapter, we strove to provide an international reader with a glimpse of the current trends in research in mathematics education in the Czech Republic and in Slovakia and the roots from which they stem. One of these can be found within Comenius's principles. Comenius's influence can be traced not only in mathematics education but in education in general. However, many of his ideas are taken for granted by researchers in $\mathrm{CZ}$ and $\mathrm{SK}$ and often used without explicit reference to their proponent. They are also well known among practising teachers, though more often than not on the level of proclamation.

In $\mathrm{CZ}$, research in mathematics education has mostly been concentrated around faculties preparing teachers and in the Institute of Mathematics of the Czech Academy of Sciences. Nowadays, mathematics education is recognised as a scientific field. There are doctoral studies in mathematics education and researchers can reach habil- 
itation or professorship in this field. Researchers have ample opportunities to present their work at international conferences. There has been an effort to bring together researchers from the didactics of different subjects to get new insights and develop a common scientific language, with a view that fields with developed didactics such as mathematics help the fields that have been newly established. One of the indicators of this effort was the establishment of a scientific journal aimed at mathematics, physics and sciences education: Scientia in educatione (www.scied.cz).

In addition, research in mathematics education must face old and new challenges. The challenges include an insufficient number of grant projects to be awarded to researchers in education (as opposed to researchers in sciences or medicine), a growing pressure on researchers to publish all the time (so that they put a lot of energy into publishing partial results; prefer small-scale, short-term studies and do not have enough time to devote to publishing studies aimed at using research results in practice), insufficient financial means for doctoral students, and a lack of career incentives for them, which has had effects such as a decrease in the number of Ph.D. students, and research in mathematics education not developing equally in all universities educating teachers.

In terms of mathematics education research in CZ and SK, we can see, for example, the need to conduct long-term empirical research investigating the influence of certain types of teaching (such as the above scheme-based teaching of mathematics, which has been used by an increasing number of schools in CZ) on pupils' mathematical knowledge. More attention is needed on research on the upper-secondary school level, as research of elementary and lower-secondary school levels prevails.

Much work in mathematics education in $\mathrm{CZ}$ and $\mathrm{SK}$ has investigated mathematical content and its elaboration for teaching (especially in the context of teaching with the help of technology) without taking into account pupils, teachers and the whole sociocultural context of the class and society. Proper methodology is needed. Moreover, it seems to us that some studies do not build on existing research results in the investigated topic, without which the field will not advance.

Another possibility for development can be seen in mutual cooperation among researchers from different disciplines. While there has been enough contact with mathematics, cooperation with pedagogy and psychology is needed. Teams of researchers from these fields working on a common topic are not frequent in $\mathrm{CZ}$ and SK. ${ }^{18}$

Finally, let us reiterate that even though we have tried to be as rigorous as possible and ground the above account in publications available to us, the text naturally represents our own personal perspective.

Acknowledgements The article was supported by research Progress Q17 Teacher Preparation and the Teaching Profession in the Context of Science and Research (Novotná and Vondrová) and by RVO: 67985840 (Tichá).

\footnotetext{
${ }^{18}$ There have been some exceptions, for example, researchers from mathematics education, psychology and linguistics cooperating within a GA ČR project on word problems, researchers from linguistics and mathematics education working on CLIL issues and researchers from different fields investigating professional vision of student teachers and possibilities for their development.
} 


\section{References}

Benke, G., Hošpesová, A., \& Tichá, M. (2008). The use of action research in teacher education. In K. Krainer \& T. Wood (Eds.), Participants in mathematics teacher education; individuals, teams, communities and networks (The international handbook of mathematics teacher education (Vol. 3, pp. 283-330). Rotterdam: Sense Publishers.

Beňačka, J., \& Čeretková, S. (2015). Graphing functions and solving equations, inequalities and linear systems with pre-service teachers in excel. In K. Krainer \& N. Vondrová (Eds.), Proceedings of the Ninth Congress of the European Society for Research in Mathematics Education (pp. 2311-2318). Prague, Czech Republic: Charles University in Prague, Faculty of Education and ERME.

Bero, P. (1993). Calculations in the style of Kepler. For the Learning of Mathematics, 13(3), 27-30.

Binterová, H., \& Fuchs, E. (2014). How to teach mono-unary algebras and functional graphs with the use of computers in secondary schools. International Journal of Mathematical Education in Science and Technology, 45(5), 742-754. https://doi.org/10.1080/0020739x.2013.877604.

Binterová, H., Hošpesová, A., \& Novotná, J. (2006). Constitution of classroom environment: Case Study. In D. Clarke, Ch. Keitel \& Y. Shimizu (Eds.), Mathematics classrooms in twelve countries: The insider's perspective (pp. 275-288). Rotterdam: Sense Publishers.

Brousseau, G. (1997). Theory of didactical situations in mathematics 1970-1990 (N. Balacheff, M. Cooper, R. Sutherland \& V. Warfield, Eds. \& Trans.). Dordrecht: Kluwer Academic Publishers.

Brousseau, G. (2011). Základy a metódy Didaktiky matematiky [Basics and methods of mathematics education]. (I. Trenčanský et al., Eds. \& Trans.). Bratislava: Univerzita Komenského, FMFI.

Brousseau, G. (2012). Úvod do Teorie didaktických situací v matematice [Introduction into the Theory of Didactical Situations in Mathematics]. (G. Brousseau, J. Novotná, J. Bureš, L. Rủžičková, Trans.). Prague: Univerzita Karlova v Praze - Pedagogická fakulta.

Budínová, I. (2017). Progressive development of perception of the concept of a square by elementary school pupils. In J. Novotná \& H. Moraová (Eds.), Proceedings of SEMT '17. Equity and Diversity in Elementary Mathematics Education (pp. 109-118). Prague: Charles University, Faculty of Education.

Cachová, J. (2011). Kalkulačka v elementární aritmetice [Calculator in elementary arithmetic]. In A. Hošpesová, F. Kuřina, J. Cachová, J. Macháčková, F. Roubíček, M. Tichá \& J. Vaníček (Eds.), Matematická gramotnost a vyučování matematice (pp. 111-150). České Budějovice: Jihočeská univerzita.

Cihlář, J., Eisenmann, P., \& Krátká, M. (2015). Omega Position - A specific phase of perceiving the notion of infinity. Scientia in educatione, 6(2), 51-73. http://scied.cz/index.php/scied/article/ view/184. Accessed 8 January 2018.

Clarke, D., Díez-Palomar, J., Hannula, M., Chan, M. C. E., Mesiti, C., Novotná, J. ... Dobie, T. (2016). Language mediating learning: The function of language in mediating and shaping the classroom experiences of students, teachers and researchers. In C. Csíkos, A. Rausch \& J. Szitányi (Eds.), Proceedings of the 40th Conference of the International Group for the Psychology of Mathematics Education (Vol. 1, pp. 349-374). Szegéd: PME.

Duatepe-Paksu, A., Rybanský, L'., \& Žilková, K. (2017). The content knowledge about rhombus of Turkish and Slovak pre-service elementary teachers. In J. Novotná \& H. Moraová (Eds.), Proceedings of SEMT '17. Equity and Diversity in Elementary Mathematics Education (pp. 158-168). Prague: Charles University, Faculty of Education.

Dubinsky, E., \& McDonald, M. (1999). APOS: A constructivist theory of learning in undergraduate mathematics education research. In D. Holton (Ed.), The teaching and learning of mathematics at university level: An ICMI Study (pp. 275-282). Dordrecht: Kluwer Academic Publishers.

Eisenmann, P., Novotná, J., Přibyl, J., \& Břehovský, J. (2015). The development of a culture of problem solving with secondary students through heuristic strategies. Mathematics Education Research Journal, 27(4), 535-562.

Freudenthal, H. (1972). Mathematics as an educational task. Dordrecht: D. Reidel Publishing Company. 
Freudenthal, H. (1986). Didactical phenomenology of mathematical structures. Dordrecht: Kluwer Academic Publishers.

Freudenthal, H. (1991). Revisiting mathematics education. The Netherlands. Dordrecht: Kluwer Academic Publishers.

Gerrig, R. J. (1991). Text comprehension. In R. J. Sternberg \& E. E. Smith (Eds.), The psycholgy of human thought (pp. 244-245). Cambridge: Cambridge University Press.

Hejný, M. (2012). Exploring the cognitive dimension of teaching mathematics through schemeoriented approach to education. Orbis scholae, 6(2), 41-55.

Hejný, M. (2014). Vyučování orientované na budování schémat: Aritmetika 1. stupně [Teaching oriented at building schemes: Elementary arithmetic]. Prague: PedF UK.

Hejný, M., Bálint, L., Benešová, M., Bereková, H., Bero, P., Frantiková, L. ... Vantuch, J. (1988). Teória vyučovania matematiky 2 [The theory of teaching mathematics 2]. Bratislava: SPN.

Hejný, M. (2006). Diversity of students' solutions of a word problem and the teachers' educational style. In A. Simpson (Ed.), Retirement as process and concept a festschrift for Eddie Gray and David Tall (pp. 109-117). Prague: Charles University, Faculty of Education.

Hejný, M., \& Kuřina, F. (2009). Dítě, škola, matematika. Konstruktivistické přístupy k vyučování [Child, school, mathematics. Constructivist approaches to teaching]. Prague: Portál.

Hill, H. C., Blunk, M. L., Charalambous, C. Y., Lewis, J. M., Phelps, G. C., Sleep, L., et al. (2008). Mathematical knowledge for teaching and the mathematical quality of instruction: An exploratory study. Cognition and Instruction, 26(4), 430-511. https://doi.org/10.1080/07370000802177235.

Hošpesová, A., Kuřina, F., Cachová, J., Macháčková, J., Roubíček, F., Tichá, M., et al. (2011). Matematická gramotnost a vyučování matematice [Mathematical literacy and teaching mathematics]. České Budějovice: Jihočeská univerzita.

Hošpesová, A., \& Tichá, M. (2015). Problem posing in primary school teacher training. In F. M. Singer, N. Ellerton \& J. Cai (Eds.), Mathematical problem posing: From research to effective practice (pp. 433-447). New York: Springer Science + Business Media.

Hruša, K. (1962). Metodika počtů pro pedagogické instituty 1, 2 [Teaching methodology of counting for pedagogical institutes]. Prague: SPN.

Huclová, M., \& Lombart, J. (2011). Rizika nahrazení rýsování na papír konstruováním pomocí ICT při školní výuce geometrie [Risks in substituting constructions on paper with constructions with the help of ICT when teaching school geometry]. In Sborník př́spěvki̊ 5. konference Užití počítačů ve výuce matematiky (pp. 157-174). České Budějovice: Jihočeská univerzita.

Jackson, R. (2011). The origin of Camphill and the social pedagogic impulse. Educational Review, 63(1), 95-104. https://doi.org/10.1080/00131911.2010.510906.

Janáčková, M. (2006). How the task context influences the task resolving. Acta Didactica Universitatis Comenianae Mathematics, 6, 13-24.

Jančařík, A., \& Novotná, J. (2013). E-didactical shift. In Kvasnička, R. (Ed.), 10 ${ }^{\text {th }}$ International Conference on Efficiency and Responsibility in Education, Proceedings (pp. 240-247). Prague: Czech University of Life Sciences.

Jirotková, D. (1998). Pojem nekonečno v geometrických představách studentů primární pedagogiky [The concept of infinity in geometric images of future elementary teachers]. Pokroky matematiky, fyziky a astronomie, 43(4), 326-334.

Jirotková, D. (2012). A tool for diagnosing teachers' educational styles in mathematics: development description and illustration. Orbis scholae, 6(2), 69-83.

Jirotková, D., \& Littler, G. (2002). Investigating cognitive and communicative processes through children's handling with solids. In A. D. Cockburn \& E. Nardi (Eds.), Proceedings of the 26th Conference PME (pp. 145-152). Norwich: University of East Anglia.

Jirotková, D., \& Slezáková, J. (2013). Didactic environment bus as a tool for development of early mathematical thinking. In J. Novotná \& H. Moraová (Eds.), Proceedings of SEMT '13. Tasks and Tools in Elementary Mathematics (pp. 147-154). Prague: Charles University, Faculty of Education. 
Kapounová, J., Majdák, M., \& Novosad, P. (2013). Evaluation of e-learning courses for lifelong learning. In M. Ciussi \& M. Augier (Eds.), Proceedings of the 12th European Conference on e-Learning (pp. 173-183). France: Sophia Antipolis.

Kaslová, M. (2017). Diversity of results in research in the domain of pre-school mathematics at kindergarten. In J. Novotná \& H. Moraová (Eds.), Proceedings of SEMT '17. Equity and Diversity in Elementary Mathematics Education (pp. 255-264). Prague: Charles University, Faculty of Education.

Kohanová, I. (2007). Assessing the attainment of analytic - Descriptive geometrical thinking with new tools. In D. Pitta-Pantazi \& G. Philippou (Eds.), Proceedings of CERME 5 (pp. 992-1011). Larnaca: University of Cyprus.

Koman, M., \& Tichá, M. (1986). Základní výzkum vyučování matematice na 1. stupni základní školy [Fundamenal research in the teaching of elementary mathematics]. In Sborník semináře Matematika a výpočetní technika ve studiu učitelství pro 1.-4. ročník ZŠ (pp. 120-133). Prague: PedF UK.

Koman, M., \& Tichá, M. (1988). Basic research in didactics of mathematics in Czechoslovakia. Comment to the development of the functional and algorithmic approaches to problem solving. Prague: MÚ ČSAV.

Koman, M., Kuřina, F., \& Tichá, M. (1986). Some problems concerning teaching geometry to pupils aged 10 to 14 years. In R. Morris (Ed.), Studies in mathematics education: Teaching of geometry (Vol. 5, pp. 81-96). Paris: UNESCO.

Kopáčová, J., \& Žilková, K. (2015). Developing children's language and reasoning about geometrical shapes - A case study. In J. Novotná \& H. Moraová (Eds.), Proceedings of SEMT'15. Developing Mathematical Language and Reasoning (pp. 184-192). Prague: Charles University, Faculty of Education.

Kraemer, E. (1986). Vývoj školské matematiky a didaktiky matematiky v ČSR v období 1945-1985 [Development of school mathematics and mathematical education in Czechoslovakia between 1945 and 1985]. In I. Netuka (Ed.), Vývoj matematiky v ČSR vobdobí 1945-1985 a její perspektivy (pp. 184-204). Prague: Univerzita Karlova.

Krpec, R. (2016). Isomorphism as generalization tool (in combinatorics). Didactica Mathematicae, $38,107-147$.

Krygowská, Z. (1977). Zarys dydaktyki matematyki 1-3. Warszawa: Wydawnictwa Szkolne i Pedagogiczne.

Kuřina, F. (1976). Problémové vyučování v geometrii [Problem teaching in geometry]. Prague: SPN.

Kuřina, F., Tichá, M., \& Hošpesová, A. (1998). What geometric ideas do the pre-schoolers have? Journal of the Korea Society of Mathematical Education Series D: Research in Mathematical Education, 2(2), 57-69.

Kvasz, L. (2016). Princípy genetického konštruktivizmu [Principles of genetic constructivism]. Orbis Scholae, 10(2), 15-45.

Maviglia, D. (2016). The main principles of modern pedagogy in 'Didactica Magna' of John Amos Comenius. Creative Approaches to Research, 9(1), 57-67.

Marcinek, T., \& Partová, E. (2011). Measures of mathematical knowledge for teaching: Issues of adaptation of a U.S.-developed instrument for the use in the Slovak Republic. In J. Novotna \& H. Moraová (Eds.), Proceedings of SEMT '11. The Mathematical Knowledge Needed for Teaching in Elementary Schools (pp. 229-236). Prague: Charles University, Faculty of Education.

Marsh, D., \& Langé, G. (Eds.). (1999). Implementing content and language integrated learning. Jyväskylä, Finland: Continuing Education Centre, University of Jyväskylä.

Mikulčák, J. (2010). Příprava učitelů matematiky [Preparation of mathematics teachers]. In J. Mikulčák (Ed.), Nástin dějin vyučování v matematice (a také školy) v českých zemích do roku 1918 (pp. 272-284). Prague: Matfyzpress.

Ministry of Education, Youth and Sport. (2001). National programme for the development of education in the Czech Republic. White paper. Prague: The Institute for Information on Education. 
Mishra, P., \& Koehler, M. J. (2006). Technological pedagogical content knowledge: A new framework for teacher knowledge. Teachers College Record, 108(6), 1017-1054.

Moraová, H., \& Novotná, J. (2017). Higher order thinking skills in CLIL lesson plans of preservice teachers. In J. Novotná \& H. Moraová (Eds.), International Symposium Elementary Maths Teaching SEMT '17, Proceedings (pp. 336-345). Prague: Charles University, Faculty of Education.

Novotná, J., \& Hošpesová, A. (2010). Linking in teaching linear equations - Forms and purposes. The case of the Czech Republic. In Y. Shimizu, B. Kaur, R. Huang \& D. Clarke (Eds.), Mathematical tasks in classrooms around the world (pp. 103-117). Rotterdam: Sense Publishers.

Novotná, J., \& Hošpesová, A. (2013). Students and their teacher in a didactical situation: A case study. In B. Kaur, G. Anthony, M. Ohtani \& D. Clarke (Eds.), Student voice in mathematics classrooms around the world (pp. 133-142). Rotterdam: Sense Publishers.

Novotná, J., \& Hošpesová, A. (2014). Traditional versus investigative approaches to teaching algebra at the lower secondary level: The case of equations. In F. K. S. Leung, K. Park, D. Holton \& D. Clarke (Eds.), Algebra teaching around the world (pp. 59-79). Rotterdam: Sense Publishers.

Novotná, J., Lebethe, A., Rosen, G., \& Zack, V. (2003). Navigating between theory and practice. Teachers who navigate between their research and their practice. Plenary panel. In N. A. Pateman, B. J. Dougherty \& J. Zilliox (Eds.), Proceedings PME 27 (Vol. 1, pp. 69-99). Hawai'i: Joseph: University of Hawai'i, CRDG, College of Education.

Novotná, J., Margolinas, C., \& Sarrazy, B. (2013). Developing mathematics educators. In M. A. Clements, A. J. Bishop, C. Keitel, J. Kilpatrick \& F. K. S. Leung (Eds.), Third international handbook of mathematics education (pp. 431-457). New York: Springer.

Novotná, J., \& Moraová, H. (2005). Cultural and linguistic problems of the use of authentic textbooks when teaching mathematics in a foreign language. ZDM Mathematics Education, 37(2), 109-115.

Partová, E., \& Marcinek, T. (2015). Third graders' representations of multiplication. In J. Novotná \& H. Moraová (Eds.), Proceedings of SEMT '15. Developing Mathematical Language and Reasoning (pp. 267-275). Prague: Charles University, Faculty of Education.

Partová, E., Marcinek, T., Žilková, K., \& Kopáčová, J. (2013). Špecifické matematické poznatky pre vyučovanie [Specific mathematical knowledge for teaching]. Bratislava: Vydavateľstvo UK.

Pavlovičová, G., \& Barcíková, E. (2013). Investigation in geometrical thinking of pupils at the age of 11 to 12 through solving tasks. In J. Novotná \& H. Moraová (Eds.), Proceedings of SEMT '13. Tasks and Tools in Elementary Mathematics (pp. 228-235). Prague: Charles University, Faculty of Education.

Polya, G. (1945). How to solve it. A new aspect of mathematical method. Princeton: Princeton University Press.

Rendl, M., Vondrová, N., et al. (2013). Kritická místa matematiky na základní škole očima učiteli̊ [Critical places of primary school mathematics in the eyes of teachers]. Prague: Univerzita Karlova, Pedagogická fakulta.

Ripková, H., \& Šedivý, J. (1986). Teorie vzdělávání v matematice [Theory of education in mathematics]. Pokroky matematiky, fyziky, astronomie, 31(6), 348-351.

Robová, J. (2012). Informační a komunikační technologie jako prostředek aktivního př́stupu žáků $k$ matematice [Informational and communication technologies as a means of pupils' active approach to mathematics]. Prague: Univerzita Karlova, Pedagogická fakulta.

Robová, J. (2013). Specific skills necessary to work with some ICT tools in mathematics effectively. Didactica Mathematicae, 35, 71-104.

Samková, L., \& Hošpesová, A. (2015). Using concept cartoons to investigate future teachers' knowledge. In K. Krainer \& N. Vondrová (Eds.), Proceedings of CERME9 (3241-3247). Prague: Faculty of Education, Charles University and ERME.

Sedláček, L. (2009). A study of the influence of using dynamic geometric systems in mathematical education on the level of knowledge and skills of students. Acta Didactica Universitatis Comenianae Mathematics, 9, 81-108.

Semadeni, Z. (1985). Nauczanie poczatkowe matematyki. Warszawa: Wydawnictwa Szkolne i Pedagogiczne. 
Shulman, L. S. (1986). Those who understand: knowledge growth in teaching. Educational Researcher, 15(2), 4-14. https://doi.org/10.3102/0013189x015002004.

Sikorová, Z. (2011). The role of textbooks in lower secondary schools in the Czech Republic. IARTEM e-Journal, 4, 1-22.

Simpson, A., \& Stehlíková, N. (2006). Apprehending mathematical structure: A case study of coming to understand a commutative ring. Educational Studies in Mathematics, 61(3), 347-371. https://doi.org/10.1007/s10649-006-1300-y.

Simpson, A., Vondrová, N., \& Žalská, J. (2018). Sources of shifts in pre-service teachers' patterns of attention: The roles of teaching experience and of observational experience. Journal of Mathematics Teacher Education, 1(6), 607-630. https://doi.org/10.1007/s10857-017-9370-6.

Slavíčková, M. (2007). Using educational software during mathematics lessons at lower secondary school. Acta Didactica Universitatis Comenianae Mathematics, 7, 117-129.

Smílková, J., \& Balvín, J. (2016). Jan Amos Komenský a jeho př́nos filozofii výchovy a sociální pedagogice. [John Amos Comenius and his contribution to philosophy of education and social pedagogy.]. Prague: Hnutí R.

Stehlíková, N. (2004). Structural understanding in advanced mathematical thinking. Prague: Charles University, Faculty of Education.

Steiner, H.-G., \& Hejný, M. (Eds.) (1988). Proceedings of the International Symposium on Research and Development in Mathematics Education. Bratislava: Komenského Univerzita.

Tichá, M. (2000). Wie 11- bis 12-jährige Schüler Textaufgaben mit Brüchen begreifen. Der Mathematikunterricht, 46(2), 50-58.

Tichá, M., \& Hošpesová, A. (2006). Qualified pedagogical reflection as a way to improve mathematics education. Journal for Mathematics Teachers Education: Inter-Relating Theory and Practice in Mathematics Teacher Education, 9(2), 129-156.

Tichá, M., \& Hošpesová, A. (2013). Developing teachers' subject didactic competence through problem posing. Educational Studies in Mathematics, 83(1), 133-143.

Tichá, M., \& Koman, M. (1998). On travelling together and sharing expenses examples of investigation of situations. Teaching Mathematics and its Applications, 17(3), 117-122.

Tůmová, V., \& Vondrová, N. (2017). Links between success in non-measurement and calculation tasks in area and volume measurement and pupils' problems. Scientia in educatione, 8(2), $100-129$.

Turnau, S. (1980). The mathematical textbook for young students. Educational Studies in Mathematics, 11(4), 393-410.

Vališová, A., \& Kasíková, H. (Eds.). (2011). Pedagogika pro učitele [Pedagogy for teachers]. Prague: Grada.

Vaníček, J. (2009). Počítačové kognitivní technologie ve výuce geometrie [Computer cognitive technologies in the teaching of geometry]. Prague: Univerzita Karlova, Pedagogická fakulta.

Vankúš, P. (2008). Games based learning in teaching of mathematics at lower secondary school. Acta Didactica Universitatis Comenianae Mathematics, 8, 103-120.

Varga, T. (1976). Mathematik 1: flussdiagramme, lochkarten, warscheinlichkeit. Budapest: Akadémiai Kiadó.

Vondrová, N., Novotná, J., Havličková, R. (2018). The influence of situational information on pupils' achievement in additive word problems with several states and transformations. ZDM, Advance Online Placement, 1-15, https://doi.org/10.1007/s11858-018-0991-8

Vondrová, N., Novotná, J., \& Tichá, M. (2015). Didaktika matematiky: historie, současnost a perspektivy s důrazem na empirické výzkumy [Didactics of mathematics: History, present days and perspective with a focus on empirical research]. In I. Stuchlíková \& T. Janík (Eds.), Oborové didaktiky: vývoj - stav - perspektivy (pp. 93-122). Brno: Masarykova univerzita.

Vondrová, N., Rendl, M., Havlíčková, R., Hříbková, L., Páchová, A., \& Žalská, J. (2015). Kritická místa matematiky v řešeních žáků [Critical places of mathematics in pupils' solutions]. Prague: Nakladatelství Karolinum.

Vondrová, N., \& Žalská, J. (2015). Ability to notice mathematics specific phenomena: What exactly do student teachers attend to? Orbis scholae, 9(2), 77-101. 
Vyšín, J. (1972). Methoden zur Lösung mathematischer Aufgaben. Leipzig: Teubner.

Vyšín, J. (1973). Vědeckovýzkumná práce v teorii vyučování matematice [Scientific work in the theory of teaching mathematics]. Pokroky matematiky, fyziky a astronomie, 18(1), 32-38.

Vyšín, J. (1976). Genetická metoda ve vyučování matematice [Genetic methods in the teaching of mathematics]. Matematika a fyzika ve škole, 6, 582-593.

Vyšín, J. (1980). Čechovy podněty pro vyučování matematice [Čech's inputs for the teaching of mathematics]. Pokroky matematiky, fyziky, astronomie, 25(6), 313-317.

Wittmann, E. C. (1981). Grundfragen des Mathematikunterrichts. Wiesbaden: Vieweg.

Wittmann, E. C. (1995). Mathematics education as a "design science". Educational Studies in Mathematics, 29, 355-374.

Žilková, K., Gunčaga, J., \& Kopáčová, J. (2015). (Mis)Conceptions about geometric shapes in pre-service primary teachers. Acta Didactica Napocensia, 8(1), 27-35.

Open Access This chapter is distributed under the terms of the Creative Commons Attribution 4.0 International License (http://creativecommons.org/licenses/by/4.0/), which permits use, duplication, adaptation, distribution and reproduction in any medium or format, as long as you give appropriate credit to the original author(s) and the source, a link is provided to the Creative Commons license and any changes made are indicated.

The images or other third party material in this chapter are included in the work's Creative Commons license, unless indicated otherwise in the credit line; if such material is not included in the work's Creative Commons license and the respective action is not permitted by statutory regulation, users will need to obtain permission from the license holder to duplicate, adapt or reproduce the material.

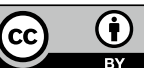

